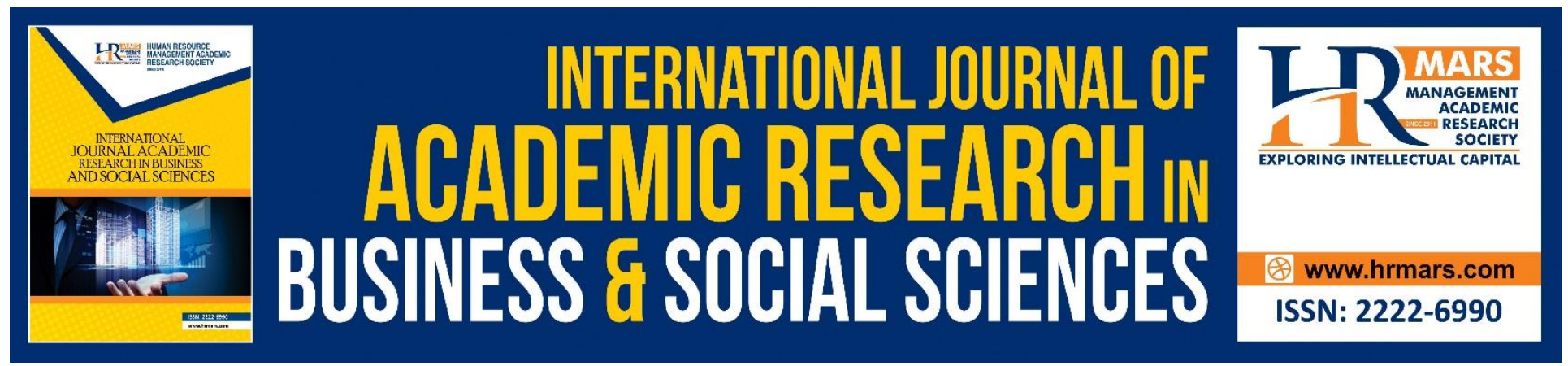

\title{
A Study on Inventory Management towards Organizational Performance of Manufacturing Company in Melaka
}

\section{Fararishah Abdul Khalid and Samantha Reina Lim}

To Link this Article: http://dx.doi.org/10.6007/IJARBSS/v8-i10/5292

DOI: $10.6007 /$ IJARBSS/v8-i10/4832

Received: 08 Sept 2018, Revised: 13 Oct 2018, Accepted: 16 Oct 2018

Published Online: 28 October 2018

In-Text Citation: (Khalid \& Lim, 2018)

To Cite this Article: Khalid, F. A., \& Lim, S. R. (2018). A Study on Inventory Management towards Organizational Performance of Manufacturing Company in Melaka. International Journal of Academic Research in Business and Social Sciences, 8(10), 1216-1227.

\section{Copyright: (C) 2018 The Author(s)}

Published by Human Resource Management Academic Research Society (www.hrmars.com)

This article is published under the Creative Commons Attribution (CC BY 4.0) license. Anyone may reproduce, distribute, translate and create derivative works of this article (for both commercial and non-commercial purposes), subject to full attribution to the original publication and authors. The full terms of this license may be seen

at: http://creativecommons.org/licences/by/4.0/legalcode

Vol. 8, No. 10, 2018, Pg. 1216 - 1227

Full Terms \& Conditions of access and use can be found at http://hrmars.com/index.php/pages/detail/publication-ethics 


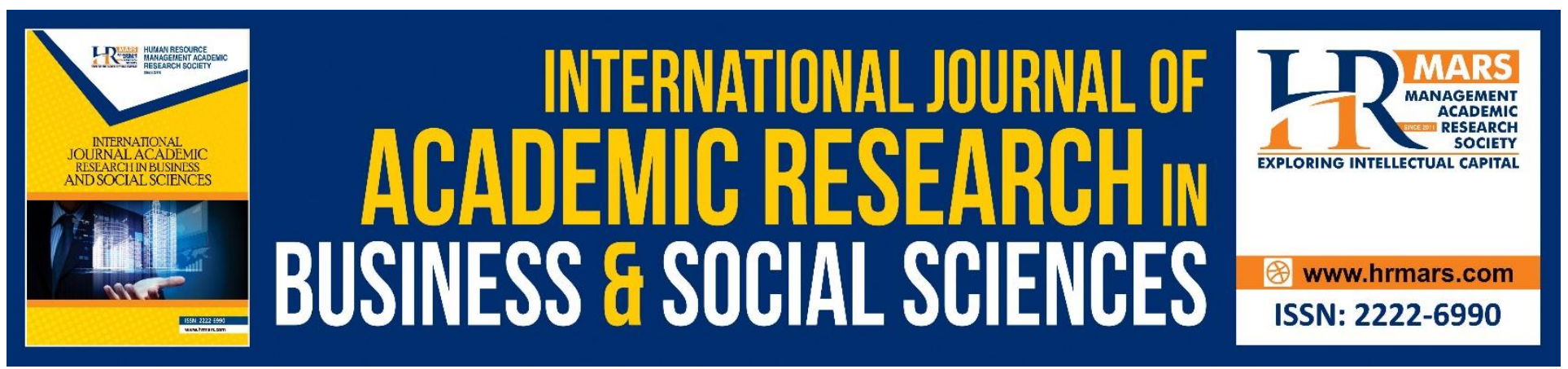

\title{
A Study on Inventory Management towards Organizational Performance of Manufacturing Company in Melaka
}

\author{
Fararishah Abdul Khalid ${ }^{1}$ and Samantha Reina Lim² \\ 1,2 Faculty of Technology Management and Technopreneurship, Universiti Teknikal Malaysia Melaka \\ Malaysia
}

\begin{abstract}
Inventory exists in almost every organization, it is crucial for an organization to have good understanding and strategy about inventory management. Inventory management has significance for an enterprise in an inventory intensive manufacturing industry (Rajeev, 2008). In this research, the researcher aimed to know the relationship between inventory management and organizational performance of manufacturing company in Melaka. Thus, the researchers identified three inventory management strategies, Vendor Managed Inventory (VMI), Material Requirement Planning (MRP), and Just-In-Time (JIT), as the independent variables to investigate the research questions. In order to collect the data and information needed, the researcher used qualitative method as the research methodology. The interviewee is aimed to be the inventory management manager of the target company. The data analysis will be using a deductive approach where all interview questions will be constructed based on the research questions, research objectives and conceptual framework. After the interview is conducted, the researcher will transcribe the script and start analysing based on the answer given by the interviewee.
\end{abstract}

Keywords: Inventory Management, Inventory Management Strategy, JIT, VMI, MRP, Organizational Performance

\section{Introduction}

Inventory exists in most of the organization, especially for manufacturing company it acts as a significant amount of current assets. As inventory plays a critical role to an organization, inaccuracies in an inventory will cause the organization to have chain problem, including loss or poor productivity, manufacture of excessive outcomes, reduction of customer loyalty, accumulation of overpricing inventory and etc. There is a trend showing that the manufacturing industry has been in rapid growth since the year 2016, and the trend is believed to continue for few more years. The growth in advance technology and innovation is also one of the potential factors that lead to the increased productivity 
in the industry. Inventory is defined as a list of goods and materials which are available in stock for business (Sharma, 2016). Statistical tests show that perceived improvements in organizational performance are associated with improvements in supply chain quality management practices (Chu Hua Kuei, 2001). High levels of inventory held in stock affect adversely the procurement performance out of the capital being held which affects cash flow leading to reduced efficiency, effectiveness and distorted functionality (Koin Violet Resia, 2014). The main purpose of this research is to investigate the relationship between inventory management and organization performance. Focusing on how inventory management can bring impact to the performance of an organization, the research goes in depth to the strategies of inventory management analyzing its pros and cons. This research is the study of inventory management towards organizational performance in Melaka. In this particular study, the research outlines the inventory strategy that potentially affects the organization performance. Based on different organization, the strategy, and technique used to manage inventory various. It identifies the relationship between inventory management and organizational performance, experimenting whether there is a positive relationship between both variables.

\section{Theoretical Background}

Inventory Management

The inventory itself has many definitions according to different people and party, top management uses different terms as well to describe the same idea. An inventory is actually a list of the items held in stock, but many people use it to mean both the list of items and the stocks themselves (Waters, 2017). As stated by Ballou (2004), inventory can be defined as the supply of raw materials, suppliers, work-in-progress, components, and finished goods that appear at numerous points throughout a firm's production and logistics process. Inventory is defined as a list of goods and materials which are available in stock for business and in accounting inventory is considered as an asset (A. Sharma, 2016). An inventory managers goal, for example, is modeled as minimizing cost or maximizing profit while satisfying customers' demands (Koumanakos, 2008). Inventory management is always about optimizing the inventory to achieve good firm performance, increase, and effectiveness and increase efficiency. Poor inventory management in production floor will cause excess or shortages of raw material which indirectly impact business performance of the company (Ooi, 2017). Management of perishable inventories is an important issue due to the need of satisfying unpredictable consumers' demand with limited supplier capabilities and storage space (Latosinski, 2017). Justified by Angel (2014), an effective inventory management must consist of six main criteria, make sure that there is an uninterrupted supply of raw materials to enable uninterrupted production process, keep enough finished manufactured goods for uninterrupted sales transactions and proficient service to customers, reduce the holding cost and period, manage assets and keep it at the best level, allow improved utilization of on hand stocks by simplifying interdepartmental handovers within a company and lastly keep enough stocks of raw materials in periods of shortage in supply and expected price increases.

\section{Vendor Managed Inventory (VMI)}

Vendor Managed Inventory (VMI) is an inbound logistics strategy based on the concept that the supplier should be in charge of management customer's inventories by using the demand information provided by the customer (Hall, 2001). VMI is also known as consignment inventory on 
other occasions, has been widely used in various industries (Yan Dong, 2002). The retailer or firm provides the vendor with access to its real-time inventory level, in which this partnership program the former may set certain servic-level or shelf-space requirements which are then taken into consideration by the vendor (Sari, 2007). Typical information sharing practices include sharing of point of sales date, demand, sales orders, inventory status, order fulfillment status and production schedules, which can help inventory management to reduce inventory cost and improve decision making capability (Nachiappan, 2005).

\section{Material Requirement Planning (MRP)}

Material Requirements Planning (MRP) is a production planning and inventory control system which have three main functions: (i) the system helps ensure that the appropriate materials are available for production and necessary products are available for customers to avoid shortage, (ii) reduces waste by maintaining only the lowest possible materials and product levels in stock, (iii) helps plan manufacturing functions, delivery schedules and purchasing (Rouse, 2014). MRP implies that for each end item a master production schedule is created, specifying delivery times and order quantities from a forecasted demand and when the inventory position of the item is less than the defined level, a new replenishment starts for the item through a purchase or manufacturing process (Segerstedt, 2006). The aim of inventory management is to establish a link between the entire production and distribution channels of product or service in order to confirm or satisfy customer requirements (Chu, 2001). With the help of MRP system, the company is able the estimate better in delivering products to customers, which will enhance company performance in long-term.

\section{Just-in-time (JIT)}

Just-in-time (JIT) was originally introduced by the Japanese back in the 1930s as one of the newest approaches in that era but was quickly adapted and practiced by organizations all over the world. JIT has been developed, because, beyond the act of an inventory control method, and it is a philosophy, the philosophy used in the production of, and seeks to remove all the waste of resources (Rahmani, 2014). The achievement of JIT main goals brings key point benefits, which are an elimination of inventories will enable the organization to control the ordering and delivering a process for meeting the production orders and organization's flexibility, and eliminating of inventories results to very low inventory carrying costs for the organization (Nemtajela, 2016). Companies applying JIT production system aim at minimizing all inventory levels and delivering the goods and services to customers on time (Salehi, 2010).

\section{Organizational Performance}

Achieving improvement or excellent in performance is one of the most important aspects to fight for. Singh et al. (2010) identified supply chain practice such as inventory management has an impact on organizational performance. Organizational performance can be measured in terms of two different perspectives, which are financial and non-financial. The organizational performance that this research will discuss is the aspect of non-financial measurement. Roth and Miller (1992) emphasize that business performance can be measured by manufacturing capabilities: (Ward et al., 1996) quality, cost, dependability, flexibility, and innovation. Manufacturing strategy literature typically 
INTERNATIONAL JOURNAL OF ACADEMIC RESEARCH IN BUSINESS AND SOCIAL SCIENCES Vol. 8, No. 10, Oct. 2018, E-ISSN: $2222-6990$ ㄷ 2018 HRMARS

defines competitive capabilities in term of quality, delivery, flexibility, and cost attributes (Roth, 1991). Competitive capabilities refer to the firm's ability to provide products with certain performance, which can win orders from competitors (Antonio, 2007). A poor or fail inventory management will contribute to a negative implication of system integration on firm's operational performance in terms of flexibility, delivery, cost and quality (Sambasivan, 2011). A flexible inventory control management is an important approach to achieving organizational performance (Ogbo, 2014).

Vickery (1997) and Antonio (2007) has stated few definitions for the term quality, delivery, flexibility, and cost; the definitions are as below:

1. Flexibility: The ability to rapidly adjust capacity so as to accelerate or decelerate production in response to changes in customer demand (responsiveness), reduce waste and delays.

2. Low Cost: The ability to minimize the total cost of production (inclusive of labor, materials, and operating costs) through efficient operations, process technology and/or scale economies.

3. Delivery Dependability: The ability to exactly meet quoted or anticipated delivery dates and quantities, and deliver quicker than competitors.

4. Quality (Conformance to Specification): The ability to manufacture a product whose operating characteristics meet established performance standards and reliability.

Theoretical Framework

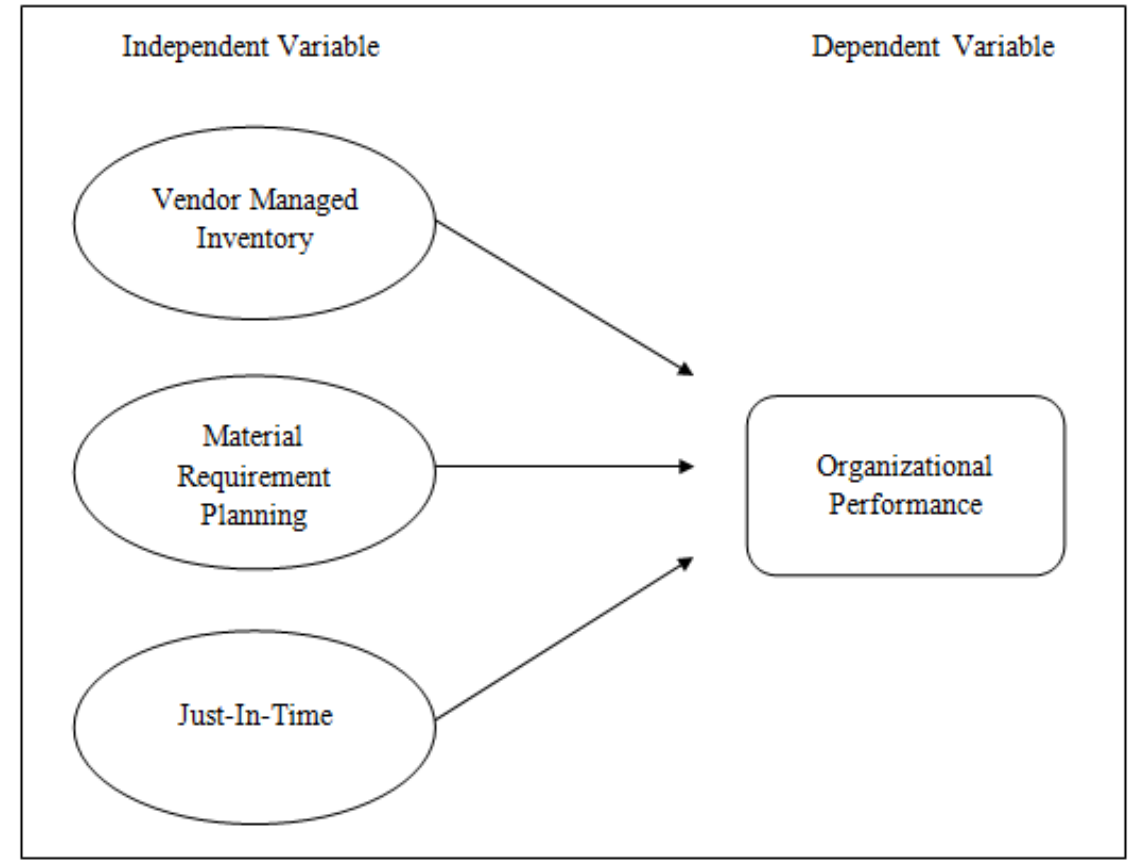

Figure 1: The conceptual framework of the study on inventory management (Vendor Managed Inventory, Material Requirement Planning, Just-In-Time) that bring impact to the organizational performance

Methodology 
This research aims to identify: (i) the inventory management strategy towards organizational performance, (ii) the relationship between inventory management strategy and organizational performance, and (iii) the most significant inventory management strategy towards organizational performance. In order to investigate three objectives, the respondent is required to be someone from the top management or is in charge of inventory as they have better understanding of the company overall performance and is able to access the big picture. Since the amount of potential respondents is constraint, and the research requires more meanings expressed through words to have better understanding on the results, thus researcher chooses to use qualitative method.

In this research, the researcher will go for non- standardised approach by using semi-structured interviews. In semi-structured interviews the researcher has a list of themes and possibly some key questions to be covered (Saunders, 2012). The questions listed might be slightly different according to different interviewee, as the interview is conducted the sequence of questions to be asked might as well be different. This research will adapt judgmental sampling in selecting respondent. Judgemental sampling is also known as purposive sampling, researcher use judgement to select target company that will best enable to answer the research questions and meet research objectives (Saunders, 2012). In this research only respondents who are dealing directly with inventory management and at the same time have the access to organizational performance will be selected. Thus, the respondent will be an inventory management manager or logistics manager. As qualitative research requires respondents to provide answer either through verbal or written form, it is crucial for the researcher to be able to interpret the main information. As mentioned by Saunders et al (2016), the task of transcribing an audio-recording is extremely time-consuming. Thus, when it comes to transcribing the interview, the researcher needs to be able to only highlight out the important and related parts. In the transcript the researcher needs to distinguish between interviewer and the interviewee and between questions and responses (Saunders, 2016).

\section{Discussion}

The most common answer received is that the respondents company is currently applying MRP, VMI, JIT in their daily operation to deal with different type of inventory. The inventory strategy is choosen based on real time situation as each inventory is suitable for different commodity. Some company are still using traditional inventory management strategy but has also bit by bit integrating to the new type of strategy as the market changes too rapidly. Smaller company tends to adopt lesser inventory management strategy whereas large organization will have multiple inventory management strategy to deal with their different type and over loaded commodity.

MRP is more like the inventory controller keys in important data or related data to enables the system to calculate future purchase of the material. Based on the requirement of different company the things to be factored in various as it needs to tie back to the organizational objectives and goals. VMI is a strategy where host company shares material usage information to the third party, vendor to enables the latter helps to make decision on the purchase of inventory or raw material. The strategy lighten the burdern of huge organization as the inventory needed to deal is in huge amount, allowing vendor to help make decision in certain commodity enhance the company overall performance and flexibility as well. Trust and good relationship is build among the organization and vendor which is an important factor for long term relationship. JIT concept is ordering the material when and only is 
needed. The organization or plant will not store excessive material for future usage. Agreement with vendor is made where they will deliver the material on a daily or weekly basis. The purpose of applying JIT is to ensure the factory has more space for other critical material.

Traditional inventory management strategy is time consuming and costly. It will lead to inefective and other negative impacts that will cause the organization to loss competitive advantages. Less factor is consider when making decision, which leads to many unseen problem in the future and controller need to solve many unnecessary problem to cover the mistake made in the first place. Traditional inventory mangement strategy is difficult to capture a sudden change or ramp in the demand usage, thus it will cause the factory or company to have problem loading materials to production line which will even cause lines down if is not deal on time. Inaccurate of usage data that origins by using the historical data is also one of the cons of the traditional inventory management as it does not have a forecast of the future but relies only on past data records.

As the company productivity runs low and become less effective due to the not up-to-date inventory management startegy, the organization top management decided to abandoned the traditional strategy and adopt the new inventory management strategy. When the market has already advanced into a new era, one must be also change to make himself capable to compete and communicate with others in the market. It is important for organization to be able to cope with the rapid change of technology, thus changing to a new inventory management strategy enhance the adaption. As the company is expanding and improving, there will be many limitation such as storage space, consumption level, cost and etc, by adopting a suitable inventory management strartegy, it can enhance the progress and enables the organization to operate effectively and effieciently.

From the answers of respondents, they agreed that there is a relationship between inventory management strategy and organizational performance. As organizational performance can be measured by the organization capabilities which are delivery, flexibiliy, cost and quality, the inventory management will also give impact on these four criteria if is not handled well. There is a linkage between both the strategy and the performance, when there is good strategy that suits the organization and meets the objective it will eventually lead to improvement of performance.

There is always risk when changing or adopting new strategy, the integration period is hard and tough but if the organization passed through the hardship, it will see a bright future awaits them. By changing from traditional to new inventory management strategy, there is improvement in the organizational performance as they are coping up with the current market demand. There is significant impact on the cost and time consumption and overall efficiency as welll. Things became more systematic and has a standard of how to deal with inventory. Improvement in the cash flow can be seen too, ordering and keeping the right amount at the right timing helps to prevent waste and lower cost.

Each company has different measurement and criteria to identify performance, this includes cost, inventory level, relationship with vendor, commitment to customer, quality and many more. As each company focus only different criteria that means the most to them, their organization goal and objective is followed by all employees to ensure they achieve the right thing, it requires all member of the organization to contribute in making it happen. Each department needs to tie their own group goal with the big picture to ensure their members are in the right path and doing the right thing that is beneficial to the organization. 
The answer of respondents is absolutely yes, as their company also take in concern the above criteria when it comes to measuring of organizational performance. It acts as one of the most common guidelines for organization to measure their performance. As all of the criteria actually links one another directly or indirectly, one wrong move may lead to poor organizational performance. An example that all is link is when an organization adopt the right inventory management strategy, it helps to optimise the inventory level preventing it from surplus or shortage which will bring impact to cost. When there is no surplus in inventory the employee will have no chance to issue an expired material to the production which iwill caused product defective and loss of quality. Also when there is no shortage of material, the production line will operates as planned and delivery the product to the hand of customer on time. When the inventory level is optimised, the organization can deal with sudden ramp in demand by having alternative material to run in the production which shows flexibility. Sometimes it is hard to determine which measure the company is using especially when they only emphasize on certain criteria, but actually in the same time they also take cares of all other measurements as well.

There is no specific one inventory management strategy that benefits the organization. In order to make improvements in the organizational performance, the organization needs to apply multiple inventory management strategy. This is because each inventory management strategy is suitable for different types of commodity thus it is important to match back the right strategy to the right inventory. Therefore there is no absolute strategy that can impact the organization performance because it depends a lot on the cooperation and decision made by people.

\section{Conclusion}

This study explores the effect of inventory management strategy towards the organizational performance in manufacturing industry in Melaka area. In this research, the researcher selected qualitative method to conduct the research where data will be collected through interview. Based on the research questions, the researcher has constructed interview questions to fulfil and meet the research objective set in the early part of the research. Then, the next step is to interview respondents that are expert in the field of inventory management strategy. The researcher has caged the potential respondent as inventory manager or logistics manager. With the development of manufacturing company, the inventory level increases through the growth of the organization. The respondent has been able to identify the most frequently used inventory management strategy that is adopted by their organization, which are material requirement planning (MRP), vendor managed inventory (VMI) and just-in-time (JIT). The most common approaches in handling inventory are material requirement planning (MRP), vendor managed inventory (VMI), flexible manufacturing system (FMS) and just-in-time (JIT) methods (Christopher, 2016). The functions of each inventory management strategy are applying the same concept among the three respondents. According to the results recorded from three of the respondents, all three agrees that there is a positive relationship between the inventory management strategy and organizational performance. One of the most common answers from the interview is "having a suitable inventory management strategy will directly or indirectly impact the organizational performance positively". A poor or fail inventory management will contribute to a negative implication of system integration on firm's operational performance in terms of flexibility, delivery, cost and quality (Sambasivan M, 2011). An appropriate 
inventory management strategy will lead to better performance as it affects the manufacturing company in terms of quality, delivery, cost, and flexibility. The respondents spotted a significant difference before and after adopting the three inventory management strategy. It is said that applying the inventory management strategy enables the company to have a better performance compared to the previous traditional strategy that is used. From the interview, the common answer when is asked to identify the most significant inventory management strategy is there is no single strategy that is able to contribute the most to organizational performance. All three respondents emphasized that to achieve a targeted goal or to have an improvement of organizational performances; the inventory management strategy is mostly a mixture of few different strategies. As each inventory management strategy is designed to suit different type of material, the inventory controller must be able to identify which strategy to use when encountering different types of material.

During the interview session, respondents mentioned about a fourth strategy that is newly adopted by their organization which is consignment method. By digging deeper through the interview, the researcher is able to obtain some basic information on how the new recommended strategy operates. Based on the explanation from the interviewee, consignment is a method where suppliers keep the material in-house but do not receive any payment from the organization until the material is used or issued to the production line. The respondent then explains that this consignment method is suitable for material that runs at a medium rate. As mentioned earlier in the previous topic, it is important for managers or inventory controller to have a clear understanding of the materials commodity and the function of each inventory management strategy. Thus, it is necessary for an organization to have courses or training that enhances the experience and skills of employees. By having better knowledge of the strategy and different commodities, the inventory planner will be able to make a flexible decision when it comes to critical situations.

\section{References}

Sharma, A. and Vivek, A. (2016). Study of Inventory Management in Manufacturing Industry. International Journal of Advanced Engineering and Global Technology, 4 (03).

Agu, OA., Ozioma, H., Nnate, E.C. (2016). Effect of Inventory Management on The Organization Performance of The Selected Manufacturing Firms. Singaporean Journal of Business Economics and Management Studies (SJBEM), 5 (4).

Borade, A.T., Bansod, S.V. (2010). Study of Vendor-Managed Inventory Practices in Indian Industries. Journal of Manufacturing Technology Management, 21(8), pp. 1013-1038.

Hou, B., Hing, K.C., Wang, X. (2013). An Account for Implementing Just-In-Time: A Case Study of The Automotive Industry in China. International Journal of Enginering and Technology Innovation, Volume 3, pp. 156-167.

Christopher, M. (2016). Logistics and supply chain management. In: Harlow: Pearson Higher Education. s.I.:s.n.

Chu,H.K., Madu, C.N., Chinco, L (2001). The relationship between suply chain quality management practices and organizational performance. International Journal of Quality \& Reliability Management, 18(8), pp. 864-872. 
Wallin, C., Rungtusanatham, M.J., Rabinovich, E. (2006). What is The "Right" Inventory Management Approach For a Purchased Item?. International Journal of Operations \& Production Management, 26(1), pp. 50-68.

Rosenzweig, E.D., A. V. Roth, A.V., Dean Jr., J.W. (2003). The Influence of An Integration Strategy on Competitive Capabilities And Business Performance: An Exploratory Study of Consumer Products Manufacturers. Journal of Operations Management, Volume 21, pp. 437-456.

Gallego, G. (2004). Columbia University. [Online] Available at: $\quad$ http://www.columbia.edu/ gmg2/4000/pdf/lect 06.pdf [Accessed 5 December 2017].

Ghauri, P.N., Gronhaug, K. (2010). Research Methods in Business Studies. Harlow: Pearson Education Limited. 4th ed. London: s.n.

Hall, C. (2001). EDM1. [Online] Available at: $\quad$ www.edm1.com/vmi.pdf/ [Accessed 6 December 2017].

Ho, C. J. (1989). Evaluating the Impact of Operating Environments on MRP System Nervousness. International Journal of Production Research, Volume 27.

Antonio, K.W.L., Yam, R.C.M., Tang, E. (2007). The Impacts of Product Modularity on Competitive Capabilities and Performance: An Empirical Study. International Journal of Production Economics, Volume 105, pp. 1-20.

Rahmani, K. (2014). Effect of JIT Implementation in Iran Automotive Industry (Case Study: Iran Khodro's Assembly Line 2). Indian J. Sci. Res., Volume 7, pp. 001-016.

Tanskanen,K., Holmstrom, J., Elfving, J. (2008). Vendor-Managed-Inventory (VMI) in Construction. International Journal of Productivity and Performance Management, 58(1), pp. 29-40.

Kenneth W. Green, Inman, R.A. (2007). The Impact of JIT-II-Selling on Organizational Performance. Industrial Management \& Data Systems, 107(7), pp. 1018-1035.

Koin, V.R., Cheruiyot, G.K., Mwangangi, P, (2014). Effect of Inventory Management of the Supply Chain Effectiveness in the Manufacturing Industry in Kenya: A Case Study of Tata Chemicals Magadi. International Journal of Social Sciences Management and Entrepreneurship, pp. 189202.

Koumanakos, D. P.(2008). The Effect of Inventory Management on Firm Performance. International Journal of Productivity and Performance Management, 57(5), pp. 355-369.

Mack, N (2015). Qualitative Research Methods: A Data Collector's Field Guide. United States: Family Health International.

Salehi, M., Alipour, M., Ramazani, M. (2010). Impact of JIT on Firms Financial Performance Some Iranian Evidence. Global Journal of Management and Business Research, 10(4), pp. 21-28.

Rouse, M., (2014). TechTarget. [Online] Available at: http://searcherp.techtarget.com/definition/material-requirements-planning-MRP [Accessed 12 December 2017].

Saunders, M., Lewis, P., Thornhill, A. (2012). Research Methods for Business Students. 6 ed. Italy: Financial Times/ Prentice Hall.

Saunders, M., Lewis, P., Thornhill, A. (2016). Research Methods for Business Students. 6 ed. Italy: Financial Times/ Prentice Hall. 
INTERNATIONAL JOURNAL OF ACADEMIC RESEARCH IN BUSINESS AND SOCIAL SCIENCES

Vol. 8, No. 10, Oct. 2018, E-ISSN: 222 2-6990 @ 2018 HRMARS

Marbum, M.P., Sinisuka, N.I., Hariyanto, N. (2015). Inventory Management Method to Determined Spare Transformer Optimization.

Nemtajela, N., Mbohwa, C. (2016). Inventory Management Models and Their Effects on Uncertain Demand.

Ogbo, A. I., Victoria, O.I., Ukpere, W.I. (2014). The Impact of Effective Inventory Control Management on Organisational Performance: A Study of 7up Bottling Company Nile Mile Enugu, Nigeria. Mediterranean Journal of Social Sciences, 5(10).

Online, T. S. (2017). The Star Online. [Online] Available at: https://www.thestar.com.my/business/businessnews/2017/05/12/manufacturing-sector-continues-to-grow/ [Accessed 2312 2017].

Ooi, C.W., Idrus, R., Abdullah, N.L. (2017). Extended ERP for Inventory Management: The Case of a Multi-National Manufacturing Company.

Öztürk, C., Örnek, A.M. (2012). A MIP Based Heuristic for Capacitated MRP Systems. Computers and Industrial Engineering, Volume 64.

Latosinski, P., and Bartoszewicz, A. (2017). Inventory Management Strategies with Higher Relative Degree Sliding Variables.

Rajeev, N.(2008). Inventory management in small and medium enterprises: A study of machine tool enterprises in Bangalore. Management Research News, 31(9), pp. 659-669.

Roth, A.V., Van Der Velde, M. (1991). Operations as Marketing: A Competitive Service Strategy. Journal of Operations Management, 10(3), pp. 303-327.

Sambasivan, M., Loke, S.P., Mohamed, Z.A., Yee, C.L. (2011). Impact of Interdependence Between Supply Chain Partners on Strategic Alliance Outcomes: Role of Relational Capital as A Mediating Construct. Management Decision, 49(4), pp. 548-569.

Sari, K. (2007). Exploring the Benefits of Vendor Managed Inventory. Journal of Physical Distribution \& Logistics Management, 37(7), pp. 529-545.

Segerstedt, A. (2006). Master Production Scheduling and a Comparison of Material Requirements Planning and Cover-time Planning. International Journal of Production Research, Volume 44, pp. 3585-3606.

Vickery, S.K., Droge, C., Markland, R.E. (1997). Dimensions of manufacturing strength in the furniture industry. Journal of Operations Management, Volume 15, pp. 317-330.

Krichanchai, S., MacCarthy, B.L. (2017). The Adoption of Vendor Managed Inventory for Hospital Pharmaceutical Supply. The International Journal of Logistics Management, 28(3), pp. 755780.

Sohal, A. S., Keller, A. Z., Fouad, R.H., (1988). A Review of Literature Relating to JIT. International Journal of Operations \& Production Management, Volume 9, pp. 15-25.

Nachiappan, S.P., Jawahar, N., Parthibaraj, S.C., Brucelee, B. (2005). Performance Anaysis of Forecast Driven Vendor Managed Inventory System. Journal of Advanced Manufacturing Systems, Volume 4, pp. 209-226.

Rossi, T., Pozzi, R., Pero, M., Cigolini, R. (2016). Improving Production Planning Through FiniteCapacity MRP. International Journal of Production Research. 
Waters, D. (2017). Inventory Management. Handbook of Logistics and Supply-Chain Management, 02 March.pp. 195-212.

Borges, W.G., Ng, S.I, Chew, B.C., Lau, T.C., Ong, La Teik, Nadarajah, D., Lee, C., Goi, M.T., Law, K.A., Mamat, M.N. (2017). Business Research Methods. Subang Jaya: SJ Learning.

Wilson, J. M. (2015). The Origin of Material Requirements Planning in Frederick W. Taylor's Planning Office. International Journal of Production Research.

Yan Dong, K. X. (2002). A Supply Chain Model of Vendor Managed Inventory. Transportation Research Part E, Volume 38, pp. 75-95. 